\title{
Cognitive Procedures in Implicit Speech Acts
}

\author{
A. V. Kuznyetsova
}

\author{
Zhytomyr Ivan Franko State University \\ Corresponding author. E-mail: maleadummin@gmail.com
}

Paper received 01.09.19; Revised 08.09.19; Accepted for publication 12.09.19.

\section{https://doi.org/10.31174/SEND-Ph2019-204VII60-15}

\begin{abstract}
The study is aimed at the analysis of cognitive procedures ( as understood in contemporary discourse and cognitive linguistics) which function in belle-lettres discourse with the use of some kinds of implicit speech acts, at proving that there exist certain similarities of these procedures and their combinations, and this fact enables authors to use and foresee text effects created by them. The author also suggests the application of the given analysis method for all types of implicit speech acts.
\end{abstract}

Keywords: implicit speech acts, cognitive procedure, belle-lettres discourse, text effect.

In cognitive linguistics a great role belongs to studying of cognitive triggers which functionate in human communication and in a discourse. An important research on the issue was made by R.W. Langacker who focused on cognitive operations that are relevant in a discourse [22], and namely: trajectory/landmark alignment; specification vs. schematization; reference point; relationship: focusing; perspectivization. This R.W. Langacker's work created the grounds for many studies in linguistics, thus we believe it important to apply the stated approach to implicit speech acts which is the research material of the given study.

There also exist more detailed classifications of cognitive operations in comprehension process than that suggested by R.W. Langacker, which include the following operations: analysis; synthesis (based on the generalization of analysis data); comparison (based on the data of the previous two operations);

abstraction (the process of mental simplification of the object by means of neglecting of some of the object's qualities which are irrelevant for its functioning in the given situation( the operation is essential for generalizing and theoretical modelling);focusing (the operation is opposite to abstraction and inevitably connected to it); generalization (mostly based on the data of the previous two operations); classification (grouping of the object's qualities of separate groups of objects on the basis of generalization); systematization (differentiation of the received data according to some previously determined principle) [5]. The given approach is mostly applied in logics; however its usage for studying linguistic material appears quite interesting.

On the basis of the given operations the researchers point out a set of definite procedures [9] which are specified in rather a detailed way:

a) procedures with qualities: combination (grouping) with the help of logical connections, exclusion of a part of a complex quality;

b) procedures with sets: specifying, combination;

c) procedures with notions: generalization, limiting, notion search as to the notion which is logically given or derived;

d) procedures with single objects generalized in notions: qualities search, comparison, defining objectquality relationship;

e) procedures with judgements: formation of a complex judgement.

The application of the suggested cognitive operations for the analysis of implicit speech acts is suggested in this paper below. It seems appropriate to specify the material of the research.

Implicit communication and implicit speech acts have repeatedly been in the focus of linguists' attention, mostly in the aspect of their ability to convey some intended meaning $[21 ; 22-24 ; 26]$, or as the cause of communication failures $[3 ; 10 ; 19 ; 23 ; 26]$. It is understandable that linguistic means which actualize implicit speech acts are hardly fit for any structuring as they do not fall into any system; but the question of definite kinds of such speech acts is far from being investigated enough.

Though the idea of various kinds of implicit speech is well-known and some particular kinds of implicit speech acts became a subject of detailed study in pragmatics and discourse linguistics $[2 ; 3 ; 6 ; 10 ; 11]$, it is important to mention, though, that no attempt has been made yet to classify implicit speech acts, and the list of different kinds of speech acts remains open. Besides, there hasn't been an attempt made to study them in a view of cognitive processes, operations or procedures.

In the article an attempt is being undertaken to study pragmatic and cognitive features of the following kinds of implicit speech types: utterances with transformed idioms and contextual (text) symbols. These speech acts are studied on the material of complete British and American belles-lettres texts, written in late XX - XXI centuries. The main research methods applied are semantic, cognitive and contextual analyses as concerns the terms of cognitive procedures mentioned above.

Utterances with transformed idioms are understood as utterances with deliberate change of the form and semantics of an idiom, caused by the author's intention to express a certain additional (or changed) sense. The study of such utterances was undertaken in the author's $\mathrm{PhD}$ dissertation and monograph [7]. It is shown in these research papers that the transformation of idioms has numerous variations and forms, though the inner form of the idiom always remains intact. Such idioms serve as the author's means to create an informational signal and to convey an additional implicit sense [7, p.197], as in the example:

As he passed by her window, he stooped a little, lifting several of his gloved fingers to his hat brim. Idiot is as idiot does. She thought him idiotic? Somebody should $[14, p .79]$.

Here the usage of the transformed idiom handsome is as handsome does (i.e., a person is judged by his actions) is observed, in which the major lexical components are 
changed by the words with contrasting semantics and axiology. The implication of the passage is as follows: the personage is a dean of a prestigious US university, who is by no means a silly person. He found himself in a foreign country where he knows neither the language, nor the traditions, that's why it is very difficult for him to understand what is what. Moreover, his departure from work happens to be a tactical mistake which is used by his opponents and can ruin his career. Here the author expresses his sympathy with his personage.

Contextual (text) symbols are understood as objects or references which add deeper meaning to the plot of the story and enhance a theme, idea or a character. Symbols are perceived on a cultural interpretation level as a result of culturally marked senses of the word or phrase which actualizes this symbol.

Contemporary linguistics understands a symbol as a sign with a motivated link with its referent [1, p. 404], and this sign represents metonymic relations between a certain notion and one of its language/speech manifestations [8, p.45]. It is pointed out that such symbols usually allow rather a varied interpretation, broadening in such a way the possibilities of the interpretative process and enriching the plot of a belles-lettres text. Symbols of a belles-lettres text attract a special reader's interest and thus turn him into an active participant of a text as a discourse component [13]. It is evident that the interpretation and study of symbols in a belles-lettres text as the manifestations of the text's concept is an important stage in its cognitive anticipation.

Our analysis is intended to show that the usage in the texts of the above mentioned kinds of implicit speech works as a cognitive signal for verbal associations which can be rather varied, depending on the volume of the reader's background knowledge. Since these verbal associations spring up by means of consciously oriented recognitions which rest upon axiological, logical and/ or emotive orientators expressed with the help of notions [25], it is considered worthy to analyse the cases of associations which cannot be directly intended and created by the writers or recognized as intended by the readers. The features of the given types of implicit speech are studied in the angle of the development of R.W. Langacker's cognitive operations that are relevant in a discourse [22], and namely: trajectory/landmark alignment; specification vs. schematization; reference point; relationship: focusing; perspectivization.

This approach is based on the well-grounded opinion that the study of implicit speech phenomena is impossible without the understanding of the main mechanisms of cognitive activity in perception and understanding of information, where 5 meta-procedures of information comprehension are specified: control, analogy, recurrence, variability and reference [4]. It is assumed in the project that the stated cognitive operations refer to the creation and perception of the kinds of implicit speech named above, though the comparative involvement may be different for each kind of these implicit speech kinds.

We intend to show in the given article that the particular and comparative involvement of the stated cognitive procedures enables to study the cognitive peculiarity of each kind of implicit speech, as well as their common cognitive fundamentals. Here is an example with a trans- formed idiom:

"Why, we haven't seen each other since our college days - ten years, is it? A bit of water has flowed under my bridge since then, I can tell you, and yours too, I'll bet" [12, p.392].

Here we can observe the transformation of the idiom much water has flowed under the bridge which leads to the stylistic effect of a litotes. In this case the transformed idiom serves as an implicit or even concealed characterization of the personage who is speaking, thus pointing out his easy-go-round attitude to life and to the people he happened to communicate with. The cognitive operations which are involved in the process of interpretation of this implicit characterization are reference point (which allows the recipient to grasp the notion involved), specification (which enables the understanding the semantic and notional changes caused by the transformation of the idiom) and focusing (which puts the notion/concept expressed by the transformed idiom into the centre of the recipient's cognitive activity and attention. The cognitive procedures most actively involved in this process are as follows:

- procedures with qualities: combination with the help of logical connections which is needed to single out the transformed idiom and understand it as such;

procedures with sets, which presuppose the combination and comparison of the basic idiom and a transformed one, thus leading to the next procedure;

- procedures with single objects, which lead to a comparison and assumption as concerns the particular implicit characterization of the personage in the analysed text fragment.

As for symbols in a belles-lettres text, it was repeatedly mentioned that they allow broad and varied interpretation, as they acquire an additional implied sense by creating contextually determined associations [21]. The analysis of the text material proved that symbols may possess various importance in text development and text interpretation. Some of them are relevant within a comparatively small text fragment, in this paper they are called local symbols, while the other symbols interpenetrate the whole body of the text, being repeated much more than once, they are called discourse-relevant symbols.

In the novel "Black \& Blue" (I. Rankin) the following local symbol can be found:

They moved on to another bar. One of his new friends was carrying an old-style Adidas bag, red plastic with a side pocket and a broken strap. He'd had one just like it at school, back when he was fourteen, fifteen.

'What have you got in there,' he joked, 'your games kit?' They laughed and slapped him on the back.

At the new place, they moved to shorts. The pub was heaving, wall-to-wall minge.[24, p.212]

On the face of it, an implied meaning of the given symbol is difficult to trace, though the young people were quite modern and not at all poor, so their use of that old thing in the following context (He'd had one just like it at school, back when he was fourteen, fifteen) symbolizes the unusual intentions of the personage's friends. Slightly further on the symbolic meaning becomes clear enough:

The Adidas bag was on the floor in front of him, unzipped. 'Now,' one of them said, 'I'll just get out my games kit.' Pliers, claw-hammer, staple-gun, electric screwdriver, and a saw. 
Night sweat, salt stinging his eyes, trickling in, trickling out again. He knew what was happening, but still didn't believe it. The two men weren't saying anything. They were laying a sheet of heavy-duty polythene out on the floor. Then they carried him and the chair on to the sheet [24, p. 214].

The repetition of the analyzed symbol shows its relevance in the extract and the development of events: the Adidas bag functions as the symbol of wicked sinister intentions of the personage's acquaintances. The anticipation of the given symbol is based on such cognitive procedures as:

a) procedures with qualities which enable the singling out of certain features of the old bag to specify its oddity in the situation described

b) procedures with single objects generalized in notions which serve a necessary basis for the formation of the implied meaning in the given context.

Let's consider a discourse-relevant symbol from the story "The Tenant" by Helen Hudson [20], in which the main characters are a married couple, the husband (from a good family, well-read, neat and art-loving) being absolutely incapable of keeping any job for at least several months and, consequently, of earning his living.

Every night she washed his shirt and her blouse and their underwear, while he polished his shoes, turning the left one over to examine the hole. She lived in dread of that hole but could do nothing about it. He had only one pair of shoes. And she knew that slowly the hole would grow and grow until one day there would be nothing but her knitted sock to shield his step (20, p.34).

She saw the hole in his left shoe. It was getting bigge. ... (20, p.36).

But she had made it up for him ... She $<>$ urged him to stay at home $<>$ Or to walk in the park in his starched shirt and narrow tie with the hole still only a pinprick in his left shoe (20, p.38).

He was paler than even now and his features even blunter, as though they were being rubbed away. And the hole in his left shoe was big as a quarter (20, p.41).

He hung like a crucifix on the wall, so far above her that she could see the soles of his feet. She saw the hole in his left shoe. It was enormous (20, p. 41).

In the text of this story we can observe the actualization of a cognitive metaphor HOLE IN THE SHOE IS HOPELESS POVERTY, and the repeated use of the hole [in the shoe] triggers readers' associations based on their every-day knowledge which can be shaped as the chain of the following assumptions: The man had a hole in his shoe $\rightarrow$ He didn't have enough money to buy new shoes $\rightarrow$ He was very poor $\rightarrow$ He had no hope for his future. Thus the hole (in the shoe) actualizes a symbol of hopeless poverty which penetrates through the whole body of the text. As for cognitive operations which are necessary in the anticipation and interpretation of this symbol, alongside with obvious specification, schematization and reference, the special role belongs to focusing (and it is typical of all belles-lettres symbols) and perspectivization, as the situation in the story is viewed from the standpoint of the male character's wife, and for her the fact of the growing hole in that shoe is the implicit index of the inevitable disaster. And the disaster comes: her husband hangs himself. The cognitive procedures operating in symbol interpretation are as follows (according to SirotkinaPrimak):

- procedures with single objects - qualities search and comparison: in the logical placement of the hole and poverty/hopelessness and defining object-quality relationship between the given object and notions;

- procedures with notions: limiting the possible cognitive field of the notions poverty and hopelessness which are actualized in the given context;

- procedures with judgements, i.e. the formation of the complex judgement which embraces the previous procedures and results in the interpretation and comprehension of the actualized symbol as a linguistic code in implicit speech.

The suggested analysis demonstrates that there can be observed certain specific features of actualization of definite cognitive operations and cognitive procedures typical of the particular kinds if implicit speech. Thus the material of the research above makes it possible to state that:

1. The most frequently observed cognitive procedures in the anticipation of the implied sense in utterances with transformed idioms are the procedures with qualities, sets and single objects.

2. Belles-lettres symbols demonstrate active procedures with qualities and single objects, discourse-relevant symbols presupposing also the cognitive procedures with judgements.

One of the directions of further research is exercising the suggested analysis methods for other kinds of implicit speech acts; it will enable substantiating common cognitive procedures for all kinds of implicit speech. The results may appear interesting for the study of the cognitive nature of implication as such

\section{ЛИТЕРАТУРА}

1. Ахманова О.С. Словарь лингвистических терминов. - М.: Сов. Энциклопедия, 1966. -608 с.

2. Бєлозьорова О.М. Дискурсивні властивості мовленнєвого акту натякання (на матеріалі сучасної німецької мови): автореф. дис. на здобуття наук. ступеня канд. філол. наук : спец. 10.02.04 - германські мови / О.М. Бєлозьорова / ХНУ імені В.Н. Каразіна. - Харків, 2007. - 20 с.

3. Бєлозьорова О. Когнітивні операції у реалізації мовленнєвого акту натякання // Каразінські читання: Людина. Мова. Комунікація. Тези доповідей XIII наукової конференції. - Харків, 2014. - С. 33-34.

4. Величковский Б.М. Когнитивная наука. - М.: Наука, 2006. $-448 \mathrm{c}$.

5. Гилев А. А. Систематизация когнитивных операций // Вестник Самарского государственного технического

университета. Психолого-педагогические науки. - 2010. - № 3 (13). - С. 27-31.

6. Киосе М. И. Лингво-когнитивные аспекты аллюзии: На материале заголовков английских и русских журнальных статей: дисс. ... канд. филол. наук: 10.02.20 / М. И. Киосе. - М., 2002. -281 c.

7. Кузнєцова Г.В. Фразеологізми з семантичними зрушеннями у сучасному англомовному художньому дискурсі: Монографія. - Житомир: Вид-во ЖДУ ім. І. Франка, 2011. $-242 \mathrm{c}$.

8. Кухаренко В.А. Интерпретация текста. - Л.: Просвещение, 1979. - 314 c.

9. Сироткина-Примак Л.С. Логико-когнитивные структуры операций с понятиями: Автореф. канд. дис. ... философских наук: 09.00.07. - Калининград, 2012. - 21 с. 
10. Тухарели М.Д. Аллюзия в системе художественного произведения: Дис. ... канд. филологических наук: 10.01.08. - Москва, 2006. - 186 с.

11. Хвощевський Р.В. Натяк як мовленнєва стратегія (на матеріалі сучасної французької мови): дис. ...канд. філол. наук:10.02.05. - К., 2002. -172 c.

12. Adler E. The Rich Shall Inherit. - L.: Hodder \& Stoughton Ltd. $-1989 .-552 \mathrm{p}$.

13. All American: Glossary of Literary Terms. - Е. pecypc. Код доступу [www2.uncp.edu/home/Canada/work/allam/general/glossary. $\mathrm{htm}]$.

14. Bellow S. The Dean's December. - N.Y.: Pocket Books. 1982. - $346 \mathrm{p}$.

15. Bull P. Communication under the Microscope. - N.Y.: Taylor \& Francis e-Library, 2003. -185 p.

16. Carson R. Linguistic Meaning. Communicated Meaning and Cognitive Pragmatics // Mind and Language/ - 2002. - V.17, No.1-2. - P.127-148.

17. Carson R. Thoughts and Utterances. The Pragmatics of Explicit Communication. - Oxford: Blackwell, 2002. - 418 p.

18. Carson R. The Explicit/Implicit Distinction in Pragmatics \& the Limits of Explicit Communication [www.langs/ci.ucl.ac.uk/.../Lodz-IRP-Expl-Impl]
19. Grewendorf G. \& G. Meggle (eds.) Speech Acts, Mind \&

Social Reality. Discussions with John Searle (Studies in Linguistics \& Philosophy). - Dordrecht: Kluwer, 2002. - 384 p.

20. Hudson H. The Tenant.//Eleven American Stories - M. Международные отношения, 1988. - C. 31-46.

21. Kirzner L.G., Mandell S.R. Fiction: Reading, Reaction, Writing. - E. pecypc. - Код доступа [http://booksgoogle.com.ua/books?id]

22. Langacker, R.W. Concept, Image and Symbol. The Cognitive Basis of Grammar / R.W. Langacker. - Berlin, New York: Mouton de Gruyter, 1990. - 395 p.

23. Pinker S. The Evolutionary Social Psychology of Off-Record Indirect Speech Acts. - Harvard: Harvard Univ. Press, 2006. $-461 \mathrm{p}$.

24. Rankin I. Black \& Blue. - L.: Orion Publishing Co, 2009. $409 \mathrm{p}$.

25. Santos A., Chaigneau S. E., Simmons W. K., Barsalou L.W. Property generation reflects word association and situated stimulation, 2010

[www.port.ac.uk/departments/academic/psychology/staff/filet down loads, 6831, en.pdf ]

26. Stillings, Neil, A., Steven E. Weisler, Christopher H. Feinstein, Jay C. Garfield and Edwina L. Rissland. Cognitive Science: An Introduction. - Massachusetts: The MIT Press, 1995.

\section{REFERENCES}

1. Ahmanova, O.S. Dictionary of linguistic terms. - М.: Сов. Энциклопедия. [M.: Sov. Encyclopedia], 1966. - 608 p.

2. Belozyorova, O.M. Discourse peculiarities of a speech act of hint (on the material of the modern German language): Theses for the Candidate Degree in Philology, speciality 10.02.04. - Germanic languages / O. M. Belozyorova / Kharkiv National Vasyl Karazin University. - Kharkiv, 2007. $-20 \mathrm{p}$.

3. Belozyorova, O.M. Cognitive operations in realization of the speech act of hint // Karazin's Readings: Man. Language. Communication. Abstracts of XIII Scientific Research Conference. - Kharkiv, 2014. - P. 33-34.

4. Velichkovskiy, B.M. Cognitive science: Foundations of epistemic psychology: in 2 volumes. - M.: Science, 2006: Publishing Centre "Academia". -448 p.

5. Gilev, A.A. Systematization of cognitive operations // Newsletter of Samara State Technological University. Psychological - Pedagogical Sciences. - 2010. - № 3 (13), 27-31.

6. Kiose, M.I. Lingual-cognitive aspects of allusion: on the material of titles of the English and Russian magazine articles: Theses for the Candidate Degree in Philology, speciality - 10. 02. 20. - Comparative-historical, typological and contrastive linguistics. / Moscow State Regional University. Moscow, 2001. -281 p.

7. Kuznyetsova, G.V. Phraseological units with semantic shifts in the modern English belles-lettres discourse: Monograph. Zhytomyr: ZhSU Press, - 2011. - 242 p.

8. Kuharenko, V.A. Интерпретация текста. - Л.: Просвещение. [Interpretation of text. - L.: Prosveshcheniye], 1979. $314 \mathrm{p}$.

9. Sirotkina-Primak, L.S. Logical-cognitive structures of operations with notions: Theses for the Candidate Degree in Philosophy, Speciality - 09.00.07. - Logics / Kaliningrad, 2012. $-21 \mathrm{p}$.

10. Tuharelli, M. D. Allusion in the system of the belles-lettres work: Theses for the Candidate Degree in Philology, speciality -10.01 .08 - Theory of literature. - Moscow State Regional University, 2006. - $186 \mathrm{p}$.

11. Hvoshchevsky, R.V. 2002. Insinuating as a speech strategy (on the material of the modern French language): Theses for the Candidate Degree in Philology, speciality - 10. 02. 05. Romance languages / R. V. Hvoshchevsky / Kyiv National Taras Shevchenko University. - Kyiv, 2002. - 172 p.
12. Adler E. The Rich Shall Inherit. - L.: Hodder \& Stoughton Ltd. $-1989 .-552 \mathrm{p}$.

13. All American: Glossary of Literary Terms. - [E. source]. [www2.uncp.edu/home/Canada/work/allam/general/glossary. htm].

14. Bellow S. The Dean's December. - N.Y.: Pocket Books. 1982. - $346 \mathrm{p}$.

15. Bull P. Communication under the Microscope. - N.Y.: Taylor \& Francis e-Library, 2003. - 185 p.

16. Carson R. Linguistic Meaning. Communicated Meaning and Cognitive Pragmatics // Mind and Language/ - 2002. - V.17, No.1-2. - P.127-148.

17. Carson R. Thoughts and Utterances. The Pragmatics of Explicit Communication. - Oxford: Blackwell, 2002. - 418 p.

18. Carson R. The Explicit/Implicit Distinction in Pragmatics \& the Limits of Explicit Communication [www.langs/ci.ucl.ac.uk/.../Lodz-IRP-Expl-Impl]

19. Grewendorf G. \& G. Meggle (eds.) Speech Acts, Mind \& Social Reality. Discussions with John Searle (Studies in Linguistics \& Philosophy). - Dordrecht: Kluwer, 2002. - 384 p.

20. Hudson H. The Tenant.//Eleven American Stories - M.: Международные отношения [International Relations], 1988. - P. 31-46.

21. Kirzner L.G., Mandell S.R. Fiction: Reading, Reaction, Writing. - Електронний pecypc [E. source]. [http://booksgoogle.com.ua/books?id]

22. Langacker, R.W. Concept, Image and Symbol. The Cognitive Basis of Grammar / R.W. Langacker. - Berlin, New York: Mouton de Gruyter, 1990. - 395 p.

23. Pinker S. The Evolutionary Social Psychology of Off-Record Indirect Speech Acts. - Harvard: Harvard Univ. Press, 2006. $-461 \mathrm{p}$.

24. Rankin I. Black \& Blue. - L.: Orion Publishing Co, 2009. $409 \mathrm{p}$.

25. Santos A., Chaigneau S. E., Simmons W. K., Barsalou L.W. Property generation reflects word association and situated stimulation, 2010. [www.port.ac.uk/departments/academic/psychology/staff/filet down loads, 6831, en.pdf ]

26. Stillings, Neil, A., Steven E. Weisler, Christopher H. Feinstein, Jay C. Garfield and Edwina L. Rissland. Cognitive Science: An Introduction. - Massachusetts: The MIT Press, 1995. 